\title{
A Study of Water Treatment Chemical Effects on Type I" Pitting Corrosion of Copper Tubes
}

\author{
Takashi Iyasu', Motoki Kuratani22, Itaru Ikeda3 ${ }^{3}$, Noriyuki Tanaka ${ }^{3}$, Yutaka Yamada², \\ Osamu Sakurada ${ }^{2}$ \\ ${ }^{1}$ Technical Support Department, Kurita Water Industries Ltd., Tochigi, Japan \\ ${ }^{2}$ Gifu University, Gifu, Japan \\ ${ }^{3}$ Technical Research Laboratory, DAI-DAN Co., Ltd., Saitama, Japan \\ Email: t.iyasu78@kurita-water.com,z4524032@edu.gifu-u.ac.jp, ikedaitaru@daidan.co.jp, tanakanoriyuki@daidan.co.jp, \\ y_yamada@gifu-u.ac.jp, sakurada@gifu-u.ac.jp
}

How to cite this paper: Iyasu, T., Kuratani, M., Ikeda, I., Tanaka, N., Yamada, Y. and Sakurada, O. (2020) A Study of Water Treatment Chemical Effects on Type I" Pitting Corrosion of Copper Tubes. Materials Sciences and Applications, 11, 494-504. https://doi.org/10.4236/msa.2020.117034

Received: June 15, 2020

Accepted: July 17, 2020

Published: July 20, 2020

Copyright $\odot 2020$ by author(s) and Scientific Research Publishing Inc. This work is licensed under the Creative Commons Attribution International License (CC BY 4.0).

http://creativecommons.org/licenses/by/4.0/

\begin{abstract}
It is known that one of the causes of pitting corrosion of copper tubes is residual carbon on the inner surface. It was confirmed that type I" pitting corrosion of the copper tube is suppressed by keeping the residual carbon amount at $2 \mathrm{mg} / \mathrm{m}^{2}$ or less, which is lower than that of the type I' pitting corrosion, or by removing the fine particles that are the corrosion product of galvanized steel pipes. The developed water treatment chemical was evaluated using three types of copper tubes with residual carbon amounts of $0 \mathrm{mg} / \mathrm{m}^{2}, 0.5$ $\mathrm{mg} / \mathrm{m}^{2}$, and $6.1 \mathrm{mg} / \mathrm{m}^{2}$. The evaluation was conducted for three months in an open-circulation cooling water system and compared with the current water treatment chemical. Under the current water treatment chemical conditions, only the copper tube with a residual carbon amount of $6.1 \mathrm{mg} / \mathrm{m}^{2}$ showed a significant increase in the natural corrosion potential after two weeks, and pitting corrosion occurred. No pitting corrosion and no increase in the natural corrosion potential were observed in any of the copper tubes that were treated with the developed water treatment chemical. In addition, the polarization curve was measured using the cooling water from this field test, and the anodic polarization of two cooling waters was compared. For copper tubes with a large amount of residual carbon, the current density near $0 \mathrm{mV}$ vs. $\mathrm{Ag} / \mathrm{AgCl}$ electrode (SSE) increased when the developed water treatment chemical was added.
\end{abstract}

\section{Keywords}

Copper Tube, Pitting Corrosion, Residual Carbon, Cooling Water System, Water Treatment 


\section{Introduction}

Copper has a high thermal conductivity and is easy to process, so it is used for heat exchangers in refrigerators and air conditioning units. Copper tubes are resistant to corrosion in freshwater but may experience pitting corrosion. It has been reported that one of the causes of this pitting corrosion is the effect of the residual carbon on the inner surface of the copper tube [1] [2] [3] [4].

The pitting corrosion of copper tubes is categorized as type I or type II. Type I pitting corrosion is further categorized into two types. One is type I' pitting corrosion when using groundwater, and the other is type I" pitting corrosion when using heat storage or cooling water [5]. To prevent these types of corrosion, it has been proposed that in the case of type I' corrosion, the concentration of free carbonic acid be reduced to less than $15 \mathrm{ppm}$ or the amount of mean residual carbon on the copper tube inner surface (hereafter referred to as "residual carbon amount") be reduced to $5 \mathrm{mg} / \mathrm{m}^{2}$ or less [6]. On the other hand, type I" is suppressed by reducing the residual carbon amount to $2 \mathrm{mg} / \mathrm{m}^{2}$ or less, which is lower than that of type I', or by filtering out fine particles that are the corrosion products of the main galvanized steel pipe [7]. However, due to the production cost of copper tubes as industrial products, the development of a water treatment chemical capable of suppressing pitting corrosion even in the presence of residual carbon is desired, rather than removing the residual carbon [8].

In this study, the corrosion suppression effect of the newly developed water treatment chemical was evaluated in a field test of an open-circulating cooling water system using copper tubes with different amounts of residual carbon. In addition, a comparison with a current water treatment chemical was performed by polarization measurement using cooling water from this field test.

\section{Methods}

\subsection{Test Materials}

Table 1 shows the types of test specimens used in the field test. The specimen material was phosphorus deoxidized soft copper tube (JIS H3300 C1220). The residual carbon amount in the tube was controlled to three different levels, 0 $\mathrm{mg} / \mathrm{m}^{2}$ (hereafter referred to as "C_0"), $0.5 \mathrm{mg} / \mathrm{m}^{2}$ (hereafter referred to as “C_0.5") and $6.1 \mathrm{mg} / \mathrm{m}^{2}$ (hereafter referred to as "C_6.1"). The C_0 and C_0.5, specimens had an outer diameter of $15.88 \mathrm{~mm}$, wall thickness of $1.0 \mathrm{~mm}$, and length of $200 \mathrm{~mm}$. The C_6.1 specimen had an outer diameter of $15.88 \mathrm{~mm}$, wall thickness of $0.8 \mathrm{~mm}$, and length of $200 \mathrm{~mm}$. They were not subjected to degreasing or other treatments. The test specimens of the field test, which were taken out every month, were cut in half along the length, and the inner surface was inspected. After removing the scale and corrosion products from each specimen with dilute sulfuric acid, the pit depth was measured with a digital microscope (VHX-5000; Keyence).

Table 2 shows the types of test specimens used in the polarization measurement. The specimen material was a phosphorus deoxidized soft copper tube 
Table 1. Description of the test specimens.

\begin{tabular}{lccc}
\hline \multicolumn{2}{c}{ Water treatment } & Development chemical & Current chemical \\
\hline $\begin{array}{l}\text { Residual } \\
\text { Carbon }\end{array}$ & 0 & C_0 A & C_0 B \\
$\left(\mathrm{mg} / \mathrm{m}^{2}\right)$ & 0.5 & C_0.5 A & C_0.5 B \\
& 6.1 & C_6.1 A & C_6.1 B \\
\hline
\end{tabular}

Table 2. Description of the test specimens.

\begin{tabular}{cccc}
\hline \multicolumn{2}{c}{ Cooling Water } & Test Water A & Test Water B \\
\hline & 0 & C_0 A & C_0 B \\
$\begin{array}{c}\text { Residual } \\
\text { Carbon }\end{array}$ & 0.5 & C_0.5 A & C_0.5 B \\
$\left(\mathrm{mg} / \mathrm{m}^{2}\right)$ & 6.1 & C_6.6 A & C_6.6 B \\
& 13.0 & C_13.0 A & C_13.0 B \\
\hline
\end{tabular}

(JIS H3300 C1220). The residual carbon amount in the tube was four types, C_0, C_0.5 and $6.6 \mathrm{mg} / \mathrm{m}^{2}$ (hereafter referred to as "C_6.6"), $13.0 \mathrm{mg} / \mathrm{m}^{2}$ (hereafter referred to as "C_13.0"). The C_6.6 and 13.0 specimens had an outer diameter of $15.88 \mathrm{~mm}$, and wall thickness of $0.8 \mathrm{~mm}$. All test specimens were half-cut that had a length of $100 \mathrm{~mm}$ that were coated with silicone resin, except for the 1 $\mathrm{cm}^{2}$ test area on its inner surface. These were degreased before the test using acetone.

\subsection{Test Equipment}

Figure 1 shows a schematic diagram of the test equipment installed in the cooling tower of the open-circulating cooling water system. There were two refrigerators of the same type, one of which was treated with a newly developed water treatment chemical (hereafter referred to as the "development chemical"), and the other with a current water treatment chemical (hereafter referred to as the "current chemical"). The development chemical was manufactured by Kurita Water Industries. and contained an oxidant-type biofouling control agent, azole-type anti-corrosive agent and phosphonic acid, and the current chemical manufactured by other companies contained a biofouling control agent, an azole-type anti-corrosive agent, and chelating agents. The test was conducted for three months, and the average water quality during the test period is shown in Table 3. Four sets of three types of test specimens were installed in each of the two systems, and the corrosion potential of the specimens was monitored every two weeks with reference to an $\mathrm{Ag} / \mathrm{AgCl}$ electrode (SSE). For the other three, one was taken out every month for corrosion inspection. The test equipment was designed to circulate water through the test specimen at a flow rate of $0.1 \mathrm{~m} / \mathrm{s}$ and then return to the cooling tower.

Figure 2 shows a schematic diagram of the polarization curve measurement equipment. The cooling water from the field test was used as the test water. The 
Table 3. Chemical compositions of the test waters.

\begin{tabular}{|c|c|c|c|c|}
\hline & & $\begin{array}{c}\text { Make up } \\
\text { water }\end{array}$ & $\begin{array}{l}\text { Circulating water } \\
\text { of development } \\
\text { chemical treatment }\end{array}$ & $\begin{array}{c}\text { Circulating water } \\
\text { of current chemical } \\
\text { treatment }\end{array}$ \\
\hline $\mathrm{pH}$ & - & 7.7 & 8.1 & 8.4 \\
\hline Conductivity & $\mathrm{mS} / \mathrm{m}$ & 17.9 & 48.1 & 69.1 \\
\hline Malkalinity (pH4.8) & $\mathrm{mgCaCO}_{3} / \mathrm{L}$ & 36 & 95 & 138 \\
\hline Total hardness & $\mathrm{mgCaCO}_{3} / \mathrm{L}$ & 59 & 173 & 255 \\
\hline Ca hardness & $\mathrm{mgCaCO}_{3} / \mathrm{L}$ & 49 & 138 & 206 \\
\hline $\mathrm{Cl}^{-}$ & $\mathrm{mg} / \mathrm{L}$ & 6 & 17 & 28 \\
\hline $\mathrm{SO}_{4}^{2-}$ & $\mathrm{mg} / \mathrm{L}$ & 20 & 65 & 101 \\
\hline $\mathrm{SiO}_{2}$ & $\mathrm{mgSiO}_{2} / \mathrm{L}$ & 21 & 59 & 86 \\
\hline Total $\mathrm{PO}_{4}$ & $\mathrm{mgT}-\mathrm{PO}_{4} / \mathrm{L}$ & - & 0.6 & 0.4 \\
\hline
\end{tabular}

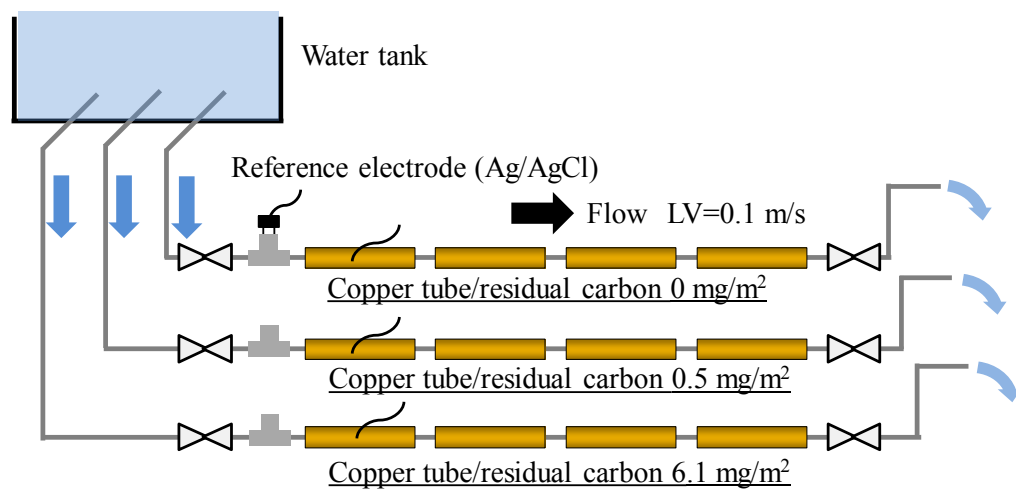

Figure 1. Schematic diagram of the test unit.

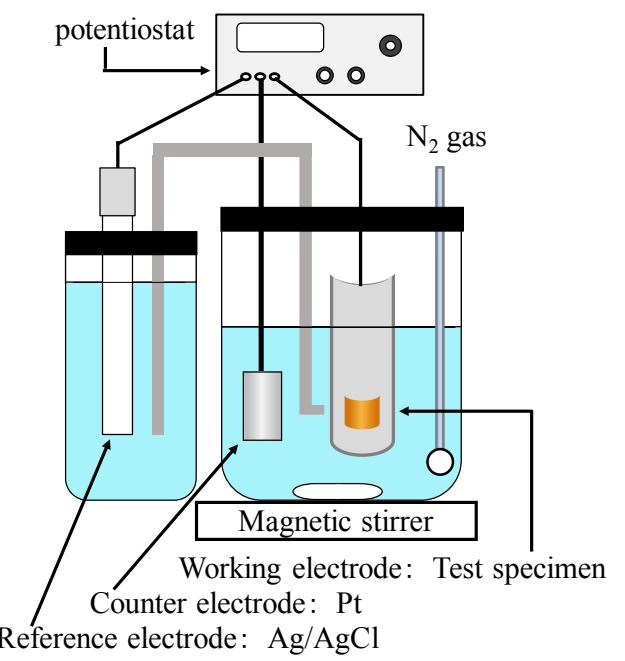

Figure 2. Schematic diagram of the polarization curve measurement apparatus. 
cooling water treated with the developed chemical was designated "test water A", and that treated with the current chemical was designated "test water B". The test water $(500 \mathrm{~mL})$ was placed in a 1-L cell container with a lid, and the polarization curves of each test specimen were measured at room temperature. The measurements were performed while stirring at a speed of $300 \mathrm{rpm}$. The anode polarization curve was measured by deoxidizing the test solution with nitrogen gas. The working electrode was the test specimen, the reference electrode was an $\mathrm{Ag} / \mathrm{AgCl}$ electrode (SSE), and the counter electrode was platinum. The polarization curve was measured three times for each material using a potentiostat (HZ-5000; Hokuto Denko) and the potentiodynamic method with a sweep speed of $20 \mathrm{mV} / \mathrm{min}$.

\section{Results and Discussion}

\subsection{Copper Tube Inner Surface Appearance}

Figure 3 shows the investigation results of the test specimens after a three-month field test. Under the development chemical treatment conditions, the surfaces of specimens C_0 A and C_0.5 A turned brown and retained their initial metallic luster. The surface of specimen C_6.1 A retained its initial metallic luster and

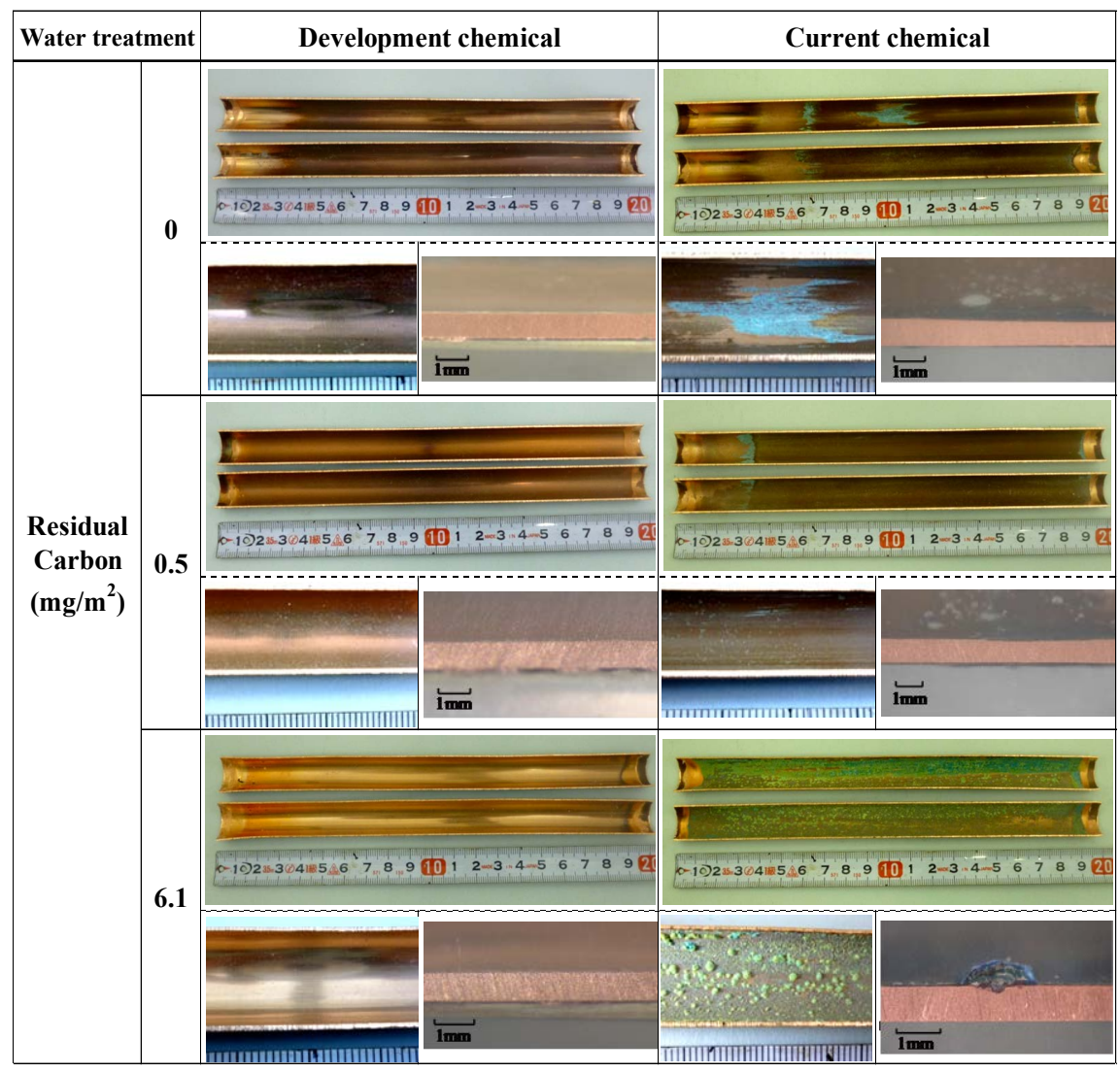

Figure 3. Observations of the inner surface of the test specimens after three months: 1 : C_0 A, 2: C_0.5 A, 3: C_6.1 A, 4: C_0 B, 5: C_0.5 B, and 6: C_6.1 B, where (a) is the inner surface, (b) is a magnified image of the inner surface, and (c) is the cross section. 
color. For all specimens, no pitting or corrosion product was observed throughout the test period. Under the development chemical treatment conditions, the copper tubes showed good corrosion resistance regardless of the residual carbon amount.

Under the current chemical treatment conditions, the surfaces of specimens C_0 B and C_0.5 B turned dark brown and had no initial metallic luster. Specimen C_0 B had a locally thin greenish corrosion product, but no pitting was observed. On the other hand, C_6.1 B exhibited many greenish-blue corrosion products on the surface, and pitting was observed under the corrosion product. Corrosion products were observed in the test specimens after one month, and it was observed that corrosion products became larger and increase in number over time. Similar to this test, pitting corrosion was reported to occur in copper tubes with residual carbon amount of $3 \mathrm{mg} / \mathrm{m}^{2}$ or more in a field test of a cooling water system, which confirmed these results [9].

\subsection{Examination of Maximum Pit Depth}

Figure 4 plots the maximum pit depths for specimens C_6.1 A and C_6.1 B during the test period. Under the current chemical treatment conditions, the pit depth increased with time for specimen $C_{-} 6.1 \mathrm{~B}$, and the maximum pit depth reached $0.075 \mathrm{~mm}$ after one month and $0.19 \mathrm{~mm}$ after three months. This value was $0.76 \mathrm{~mm} / \mathrm{y}$ when converted into one year, and it was considered that pitting progressed relatively fast. On the other hand, there was no pitting damage to C_6.1 A in the development chemical treatment.

\subsection{Measurement of the Corrosion Potential}

Figure 5 shows the measurement results of the natural corrosion potential of the test specimens. Under the development chemical treatment conditions, the natural corrosion potentials remained within the range from $40-90 \mathrm{mV}$ vs. SSE while a fluctuation of approximately $30 \mathrm{mV}$ occurred for all specimens. On the other hand, the natural corrosion potentials of specimens C_0 B and C_0.5 B, which had a low residual carbon amount, remained within the range from 0 - 60 $\mathrm{mV}$ vs. SSE, but that of specimen C_6.1 B increased to $180 \mathrm{mV}$ vs. SSE after two

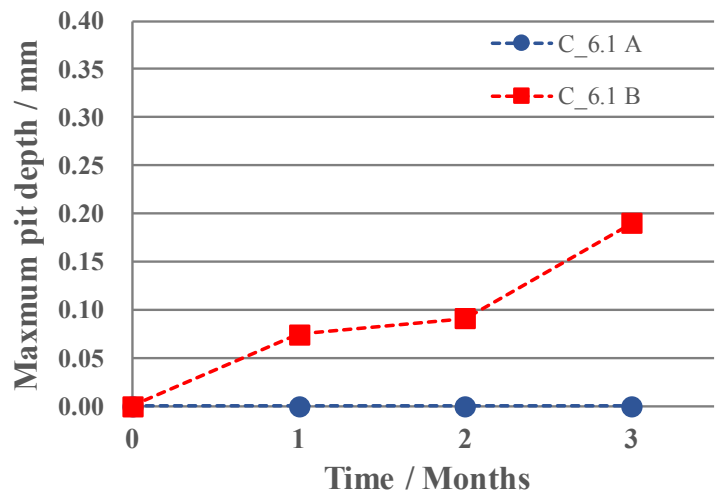

Figure 4. Change in the maximum pit depth with time. 


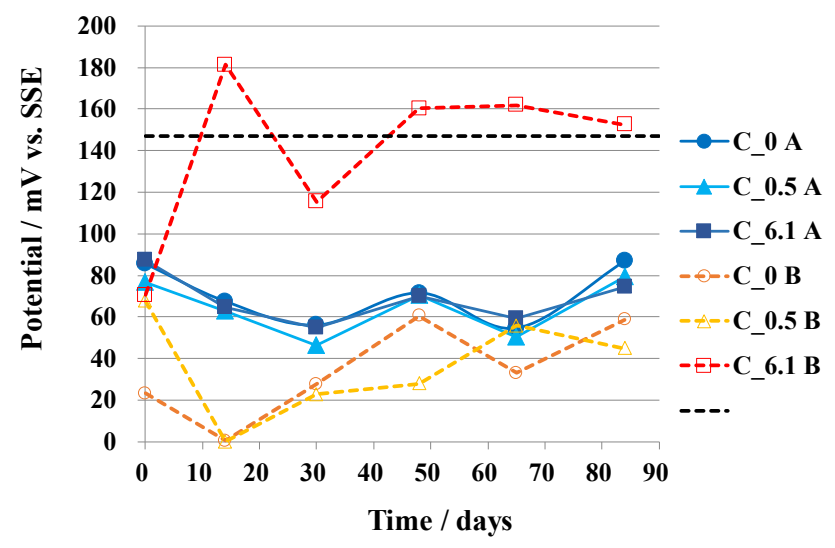

Figure 5. Potential-time curves for the test specimens.

weeks. After that, although it temporarily decreased, it remained at approximately $160 \mathrm{mV}$ vs. SSE, which was a noble value compared to that of the other copper tubes with low residual carbon amount. It has been reported that the potential for pitting corrosion affected by residual carbon is approximately $100 \mathrm{mV}$ vs. SCE (approximately $147 \mathrm{mV}$ vs. SSE in SSE conversion, broken line in Figure 5) [7]. Specimen C_6.1 B reached this potential after two weeks, and pitting was considered to have occurred during this period.

\subsection{Anodic Polarization Curve in Cooling Water}

Figure 6 shows the anodic polarization curves for each specimen in test water A. The natural corrosion potentials of specimens C_0 A and C_0.5 A, which had low amounts of residual carbon, were nobler than the potentials of specimens C_6.6 A and C_13.0 A. The behavior of the current density was similar for specimens C_0 A and C_0.5 A, increased rapidly from the natural corrosion potential and reached a maximum near $-40 \mathrm{mV}$ vs. SSE. Subsequently, the corrosion densities slowly decreased to $+100 \mathrm{mV}$ vs. SSE and then again showed a rapid rise from approximately $+120 \mathrm{mV}$ vs. SSE. The behavior of the current density was similar for specimens C_6.6 A and C_13.0 A, increased rapidly from the natural corrosion potential and reached a maximum near $-50 \mathrm{mV}$ vs. SSE. Subsequently, the corrosion densities decreased to approximately $+90 \mathrm{mV}$ vs. SSE and then again showed a rapid rise from approximately $+120 \mathrm{mV}$ vs. SSE. The current density approximately $0 \mathrm{mV}$ vs. SSE was higher in specimens C_6.6 and C_13.0 than in specimens C_0 and C_0.5.

Figure 7 shows the anodic polarization curves of each specimen in test water B. As in test water A, the natural corrosion potentials of the specimens with low residual carbon amounts were nobler than those of the specimens with high carbon amounts. The behavior of the current density was similar for specimens C_0 B and C_0.5 B, increased rapidly from the natural corrosion potential and reached a maximum near $-50 \mathrm{mV}$ vs. SSE. Subsequently, they slowly decreased to approximately $+100 \mathrm{mV}$ vs. SSE and then again showed a rapid rise from approximately $+120 \mathrm{mV}$ vs. SSE. The behavior of the current density was similar 


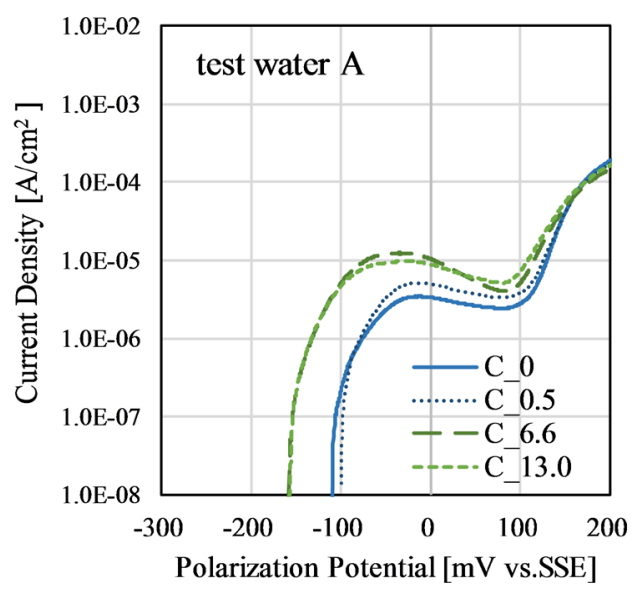

Figure 6. Anodic polarization curves of the specimens in test water A.

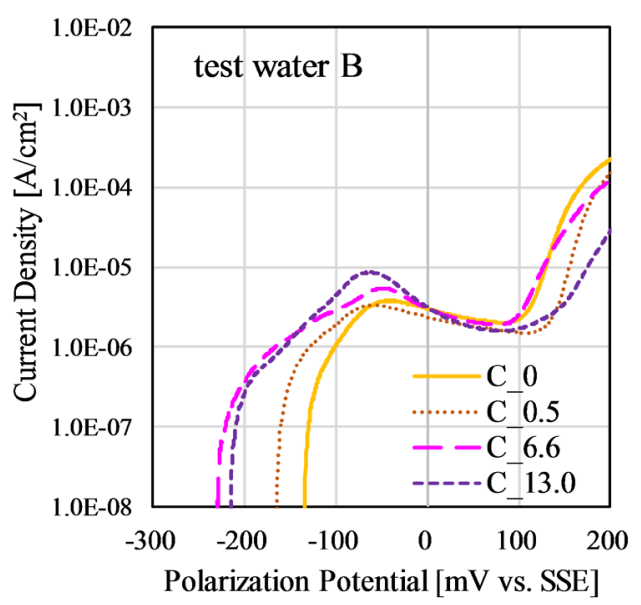

Figure 7. Anodic polarization curves of the specimens in test water B.

for specimens C_6.6 B and C_13.0 B, increased rapidly from the natural corrosion potential and reached a maximum near $-70 \mathrm{mV}$ vs. SSE. Subsequently, they decreased to around $+90 \mathrm{mV}$ vs. SSE, and then again showed a rapid rise from approximately $+120 \mathrm{mV}$ vs. SSE. For specimens C_6.6 B and C_13.0 B, the peak current density emerged near $-50 \mathrm{mV}$ vs. SSE to $-70 \mathrm{mV}$ vs. SSE. As shown in Figure 6 and Figure 7, regardless of the effect of the water treatment chemical, the natural corrosion potential of test water A was more noble than that for test water B. In addition, the current density also showed a difference near $0 \mathrm{mV}$ vs. SSE for a residual carbon amount of $6.6 \mathrm{mg} / \mathrm{m}^{2}$ or more, and the current density in test water A remained higher. Figure 8 shows the relationship between the residual carbon amount and the maximum current density in the anodic polarization measurement. It has been reported that a current density near $0 \mathrm{mV}$ vs. SSE suggests the formation of an oxide film [10]. These results indicated that copper tubes in the test water A were more likely to form an oxide film than those in test water B. Regardless of the residual carbon amount, the current densities of 


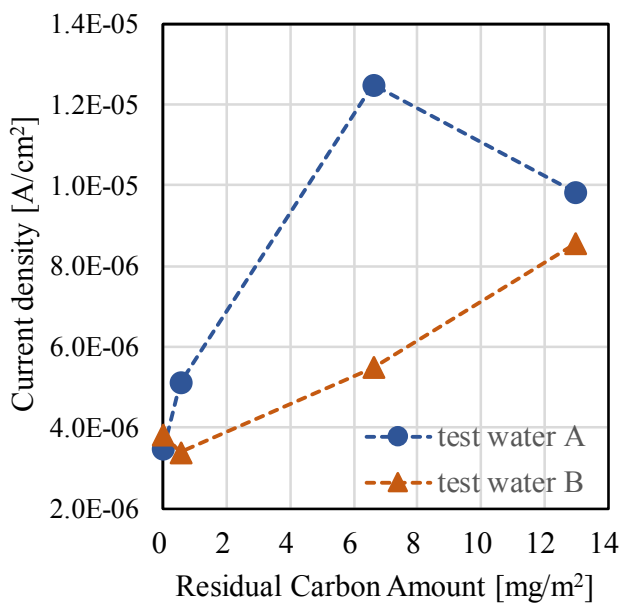

Figure 8. Relationship between the maximum current density and residual carbon amount in test waters $\mathrm{A}$ and $\mathrm{B}$.

the anodic polarization curves of both test waters A and B increased significantly from approximately $+120 \mathrm{mV}$ vs. SSE. Therefore, under the present measurement conditions, the film breakdown potential of type I" was considered to be approximately $+120 \mathrm{mV}$ vs. SSE. In test water B, the natural corrosion potential of $6.1 \mathrm{mg} / \mathrm{m}^{2}$ reached $+180 \mathrm{mV}$ vs. SSE after two weeks, and pitting corrosion appeared. Thus, there was good agreement between this consideration and the field test results.

As described above for the investigation results for the copper tube and the measurement results of the natural corrosion potential, no pitting corrosion and a significant increase in potential were observed in the development chemical regardless of residual carbon amount. It was found that pitting corrosion was greatly affected by the residual carbon amount and the water treatment chemical used. It is currently believed that the pitting corrosion inhibition of this development chemical is due to a composite film consisting of phosphonic acid, an azole type anticorrosive agent contained in the water treatment chemical, and dissolved components in the water [11]. This is still under investigation and will be clarified in the future.

\section{Conclusions}

The corrosion suppression effect of the developed water treatment chemical was evaluated in a field test of a cooling water system, and a comparison with a current water treatment chemical was performed by polarization measurements using copper tubes with different amounts of residual carbon. The results were as follows.

1) Regardless of the residual carbon amount, the test specimens with the developed water treatment chemical did not exhibit any pitting corrosion or a significant increase in the natural corrosion potential.

2) No pitting corrosion was observed at the residual carbon amount of 0.5 
$\mathrm{mg} / \mathrm{m}^{2}$ or less in the test specimens under the condition of the current chemical treatment, but at $6.1 \mathrm{mg} / \mathrm{m}^{2}$, a significant increase in natural corrosion potential and the occurrence of pitting corrosion were observed.

3) Regarding the effect of residual carbon amount, regardless of the water treatment chemical, $0 \mathrm{mg} / \mathrm{m}^{2}$ and $0.5 \mathrm{mg} / \mathrm{m}^{2}$ showed relatively close behavior, $6.6 \mathrm{mg} / \mathrm{m}^{2}$ and $13.0 \mathrm{mg} / \mathrm{m}^{2}$ showed relatively similar behavior, and the polarization behavior tended to be different when the residual carbon amount was 0.5 $\mathrm{mg} / \mathrm{m}^{2}$ or less and $6.6 \mathrm{mg} / \mathrm{m}^{2}$ or more.

4) Regarding the difference in water treatment, for copper tubes with a large amount of residual carbon, the current density near $0 \mathrm{mV}$ vs. SSE increased when the developed water treatment chemical was added.

5) Under these measurement conditions, the film breakdown potential of type I" pitting corrosion was considered to be approximately $+120 \mathrm{mV}$ vs. SSE.

6) The corrosion inhibition mechanism of the development chemical will be clarified in the future.

\section{Conflicts of Interest}

The authors declare no conflicts of interest regarding the publication of this paper.

\section{References}

[1] Cornwall, F.J., Wildsmith, G. and Gilbert, P.T. (1976) Pitting Corrosion in Copper Tubes in Cold Water Service. ASTM STP-576, 155-179. https://doi.org/10.1520/STP41404S

[2] Seri, O., Jimbo, Y. and Sakai, M. (2006) Effects of Debris and Residual Carbon Film in Circulated Water Containing a Corrosion Inhibiter on Pitting Attack of Copper Tubes for Air Conditioning System. Zairyo-to-Kankyo, 55, 505-510. https://doi.org/10.3323/jcorr.55.505

[3] Mitamura, Y., Ninomiya, M., Daikuhara, T., Inoue, Y. and Yamada, Y. (2013) Effect of Residual Free Carbon on Localized Corrosion of Copper Pipe Filled with Cooling Water during Winter Season. Journal of Japan Institute of Copper, 52, 153-157.

[4] Yamanaka, H., Nagai, T., Nonaka., H,. Tsuchiya, H. and Fujimoto, S. (2020) Effects of Deposits on Corrosion of Copper Tubes in a Circulating Cooling Water System. Zairyo-to-Kankyo, 69, 17-25. https://doi.org/10.3323/jcorr.69.17

[5] Yamada, Y., Mizutani, K. and Inoue, Y. (2014) Development of Corrosion Protection Research for Copper Tube over the Last Few Decades and Future Prospects. Zairyo-to-Kankyo, 63, 158-162.

[6] Yamada, Y., Kawano, K., Suzuki, S. and Atsumi, T. (1999) Pitting Corrosion of Copper Soft Tubes in Well Water. Zairyo-to-Kankyo, 48, 647-653. https://doi.org/10.3323/jcorr1991.48.647

[7] Yamada, Y., Mori, A., Hatanaka, R., Atsumi, T. and Nakao, N. (1998) Pitting Corrosion of Copper Coiled Tubes in the Air Conditioning System having the Open Heat Storage Water Tank. Zairyo-to-Kankyo, 47, 723-728. https://doi.org/10.3323/jcorr1991.47.723

[8] Yamada, Y. (2019) Development of Corrosion Protection Research for Copper Tube in Recent Years and Future Prospects. Refrigeration, 94, 73-77. 
[9] Mitamura, Y., Ninomiya, M., Daikuhara, T., Inoue, Y., Komukai, S. and Yamada, Y. (2012) Effect of Residual Free Carbon on Pitting Corrosion of Copper Pipe in Open Circulating Cooling Water. Journal of Japan Institute of Copper, 51, 186-190.

[10] Sakai, M., Seri, O., Yamada, Y., Toda, I. and Iitsuka, M. (2002) Effect of Residual Carbon Deposits on Corrosion Behavior of Copper Tube Filled with Water. Zairyo-to-Kankyo, 51, 12-16. https://doi.org/10.3323/jcorr1991.51.12

[11] Yamada, Y., Nagata, K. and Tagashira, K. (1992) Pitting Corrosion of Copper Tube in a Phosphonic Acid Solution. Sumitomo Light Metal Technical Reports, 33, 223-229. 